\title{
Management of ST Elevation Myocardial Infarction (STEMI) in Different Settings
}

\author{
Rod Partow-Navid, MD ${ }^{1,2}$ Narut Prasitlumkum, MD ${ }^{1,2}$ Ashish Mukherjee, MD ${ }^{1,2}$ \\ Padmini Varadarajan, MD ${ }^{1,2}$ Ramdas G. Pai, MD ${ }^{1,2}$
}

${ }^{1}$ Department of Cardiology, St Bernardine Medical Center, San Bernardino, California

2 UC Riverside School of Medicine, Riverside, California

Address for correspondence Ramdas G. Pai, MD, UCR School of Medicine, Riverside, CA (e-mail: ramdas.pai@medsch.ucr.edu).

Int J Angiol 2021;30:67-75.
Abstract
Keywords
- acute coronary syndrome
- PCI
- thrombolysis
- STEMI
- management
- review article
- different settings

ST-segment elevation myocardial infarction (STEMI) is a life-threatening condition that requires emergent, complex, well-coordinated treatment. Although the primary goal of treatment is simple to describe-reperfusion as quickly as possible-the management process is complicated and is affected by multiple factors including location, patient, and practitioner characteristics. Hence, this narrative review will discuss the recommended management and treatment strategies of STEMI in the circumstances.
ST-segment elevation myocardial infarction (STEMI) is a clinical syndrome defined by the presence of myocardial ischemic symptoms, electrocardiographic (ECG) findings of new ST-segment elevations in two continuous leads or new left bundle branch block, and subsequent detection of biomarkers indicative of myocardial injury. ${ }^{1}$ It is estimated that the annual occurrence of all MIs are 605,000 new attacks and 200,000 recurrent attacks, with an estimated annual cost of $\$ 12$ billion to hospitals. ${ }^{2,3}$ Fortunately, advances in the management of coronary heart disease have led to declining mortality rates. ${ }^{2}$ Indeed, treatment of acute MI has progressed considerably over the past 100 years, from the early stages of bed rest and "expectant" management, development of tissue plasminogen activators and their use in fibrinolysis and myocardial reperfusion, to today's current strategy with a variety of mechanical and pharmacologic modalities. ${ }^{4}$ Given the scientific and technological advantages we now have, treatment strategies can be catered to better suit the patient and their presentation. The general framework for STEMI management has been outlined in -Fig. 1.

\section{Role for Prehospital Fibrinolysis}

As mortality is high in STEMI patients with limited access to primary percutaneous coronary intervention ( $\mathrm{PCI}$ ) or coronary artery bypass grafting (CABG) as a definite treatment, the concept of prehospital fibrinolysis was constituted. Despite the inferior benefit from in-hospital fibrinolysis compared with PCI, several studies however suggested noninferior survival rates from prehospital fibrinolysis. ${ }^{5-7}$ One meta-analysis demonstrated similar rates of all-cause mortality and cardiovascular (CV) mortality as well as decreased cardiogenic shock events at the expense of increased risk of hemorrhagic stroke. ${ }^{8}$ In the US, this strategy has not been much adopted as of lack of clear benefit, particularly on hard endpoints ${ }^{9}$ as well as deficiency of medical or paramedical training especially in rural areas. ${ }^{10}$ In contrast, according to ESC guidelines, ${ }^{11}$ prehospital fibrinolysis is recommended if trained medical or paramedical staff are able to interpret the ECG onsite or transmit the ECG to the hospital for definite reading, with the aim to administer within 10 minutes after STEMI is diagnosed. ${ }^{11}$ With the advent of high-potency

(C) 2021. International College of Angiology. All rights reserved. Thieme Medical Publishers, Inc., 333 Seventh Avenue, 18th Floor, New York, NY 10001, USA
DOI https://doi.org/ 10.1055/s-0041-1723944. ISSN 1061-1711. published online

March 24, 2021 


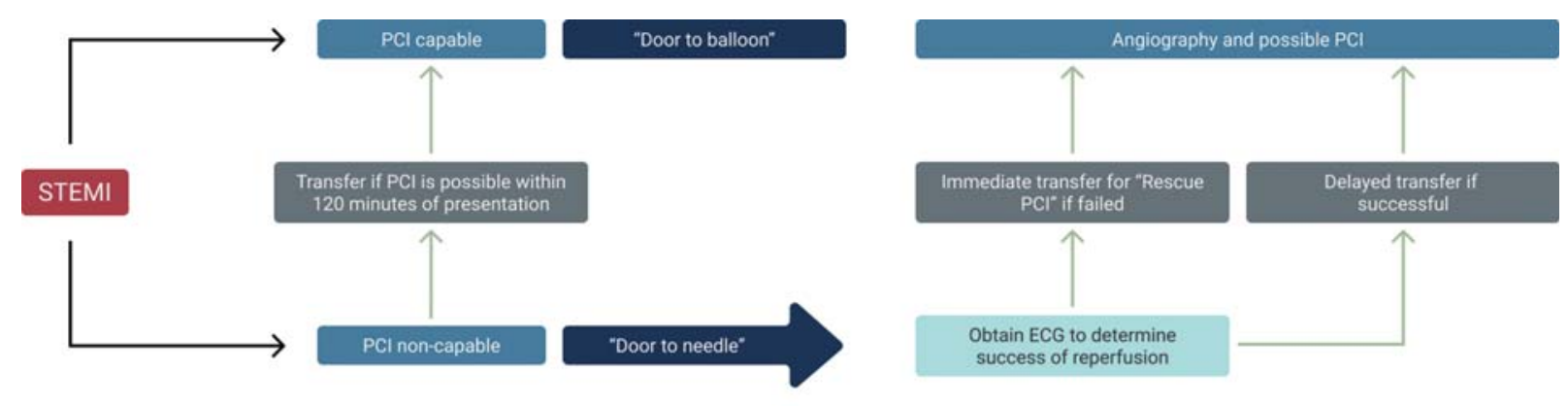

Fig. 1 General ST-segment elevation myocardial infarction (STEMI) framework-Further triaging of STEMI patient.

P2Y12 inhibitors and better medical care performance, it would be interesting if prehospital fibrinolysis in this era yielded equivalent or superior outcomes compared with more conventional strategies.

\section{Management of STEMI in a Non-PCI-capable Hospital}

Despite advances in revascularization strategies and increases in the number of hospitals that offer $\mathrm{PCI}$, circumstances remain where primary PCI is not available or there are significant delays in transfer. In the US, disparities in geographic, socioeconomic status, ethnicities and minority populations play an essential role in preventing full accessibility to $\mathrm{PCI} .^{12}$ Understandably, delay in transfer to a PCI-capable facility is associated with a significantly increased risk of mortality. ${ }^{13}$ To overcome these disparities and try to mitigate adverse outcomes, medical revascularization with fibrinolytic agents remains a necessary modality in the resource-limited setting.

Fibrinolytic therapy provides the most mortality benefit if it is given within 12 hours after symptom onset, with the largest absolute benefit if given less than 2 hours after the onset of symptoms. ${ }^{9,14-16}$ Based on this evidence, both European Society of Cardiology (ESC) and American College of Cardiology (ACC)/American Heart Association (AHA) guidelines recommended fibrinolytic therapy as initial management if PCI cannot be performed within 120 minutes of STEMI diagnosis in the absence of contraindications. ${ }^{10,11}$

- Table 1 summarizes absolute and relative contraindication to pharmacological revascularization.

As ischemic time is a major component of infarct size, time-to-treatment has a significant impact on patient outcomes. ${ }^{17,18}$ Based on the GUSTO trial, mortality rates rose significantly in accordance with time-to-needle. Similar results were shown by Berger et al, with $12.5 \%, 14.1 \%$, and $19.9 \%$ mortality rates at 30,30 to 90 , and greater than 90 minute cutoff for time-to-needle. ${ }^{19,20}$ Recently, these results were confirmed in the study by Mcnamara et al, showing higher odds of mortality if the treatment ensued within 30 to 45 minutes (1.17) and after 45 minutes (1.37), compared with treatment within 30 minutes. ${ }^{21}$ Based on the findings from the STREAM trial, the ESC has set a goal of 10 minutes from STEMI diagnosis to treatment with fibrinolytics. The names and dosages of recommended fibrinolytic agents has been summarized in - Table 2.

An ECG should be obtained between 60 to 90 minutes following fibrinolytic therapy. ${ }^{22}$ Established features of successful reperfusion are ST-segment resolution more than $50 \%$, relief of chest pain, and the presence of a reperfusion arrhythmia. Should the ST segments fail to decrease by $50 \%$, the patient should be taken for immediate angiography, commonly referred to as "rescue PCI." This is supported by the REACT trial, where patients who failed fibrinolysis were randomized into the following three groups: rescue $\mathrm{PCI}$, conservative care, and repeat fibrinolysis. ${ }^{23}$ Patients in the "rescue $\mathrm{PCl}$ " group had better outcomes, driven by a decrease in reinfarction, without a clear mortality benefit. Similar results were also seen in the MERLIN trial, where patients who failed fibrinolysis were randomized into rescue $\mathrm{PCI}$ and conservative management. ${ }^{24}$ Again, patients in the rescue $\mathrm{PCI}$ arm had a lower rate of composite end-point without a clear mortality benefit. Both ACC/AHA and ESC guidelines support the utilization of "rescue $\mathrm{PCI}$ " should a patient fail fibrinolytic therapy; however, $\mathrm{AHA}$ guidelines list a class Ila recommendation with "B" level of evidence, whereas ESC guidelines list this as a class I recommendation with "A" level of evidence. ${ }^{10,11}$

Should treatment with fibrinolytics be successful, both society guidelines still recommend transfer to a PCI-capable facility. Both the GRACIA and TRANSFER AMI studies showed improved outcomes in patients transferred for coronary angiography and revascularization following successful fibrinolysis. $^{25,26}$ Similar results have been shown in various other randomized control trials and meta-analyses. Despite the benefit of having multiple trials, the optimal time frame following fibrinolysis for coronary angiography and possible $\mathrm{PCI}$ has yet to be established. The median time frame for each trial differed as did the management strategies of oral and intravenous (IV) antiplatelets and fibrinolytics. Based on a composite of median time frames, both AHA and ESC guidelines recommend a 2- to 24-hour window following fibrinolytic therapy for angiography and possible PCI.

Although pharmacologic revascularization remains a suitable option for patients presenting to a non-PCI-capable facility, especially when there is an anticipated delay of greater than 120 minutes to primary $\mathrm{PCI}$, controversy and contraindications for fibrinolytic therapy should be considered. 
Table 1 Absolute and relative contraindication to direct fibrinolysis (adapted from ACC/AHA and ESC guidelines) ${ }^{11,59}$

\begin{tabular}{|l|l|}
\hline Absolute contraindication & Relative contraindication \\
\hline Any prior ICH & History of chronic, severe, poorly controlled hypertension \\
\hline $\begin{array}{l}\text { Known structural cerebral vascular lesion } \\
\text { (e.g., arteriovenous malformation) }\end{array}$ & $\begin{array}{l}\text { Significant hypertension on presentation } \\
\text { (SBP } 180 \mathrm{~mm} \mathrm{Hg} \text { or DBP } 110 \mathrm{~mm} \mathrm{Hg})\end{array}$ \\
\hline $\begin{array}{l}\text { Known malignant intracranial neoplasm } \\
\text { (primary or metastatic) }\end{array}$ & History of prior ischemic stroke 3 months \\
\hline Ischemic stroke within 3 months & Dementia \\
\hline Except acute ischemic stroke within 4.5 hour & $\begin{array}{l}\text { Known intracranial pathology not covered in } \\
\text { absolute contraindications }\end{array}$ \\
\hline Suspected aortic dissection & Traumatic or prolonged (10 minutes) CPR \\
\hline Active bleeding or bleeding diathesis (excluding menses) & Major surgery (3 weeks) \\
\hline Significant closed-head or facial trauma within 3 months & Recent (within 2 to 4 weeks) internal bleeding \\
\hline Intracranial or intraspinal surgery within 2 months & Noncompressible vascular punctures \\
\hline $\begin{array}{l}\text { Severe uncontrolled hypertension } \\
\text { (unresponsive to emergency therapy) }\end{array}$ & Pregnancy \\
\hline $\begin{array}{l}\text { For streptokinase, prior treatment within } \\
\text { the previous 6 months }\end{array}$ & Active peptic ulcer \\
\hline
\end{tabular}

Abbreviations: ACC, American College of Cardiology; AHA, American Heart Association; ESC, European Society of Cardiology; DBP, diastolic blood pressure; ICH, intracranial hemorrhage; SBP, systolic blood pressure.

Table 2 Recommended medications and doses for direct fibrinolysis (adapted from ACC/AHA and ESC guidelines) ${ }^{11,59}$

\begin{tabular}{|l|l|l|l|}
\hline Medication & Dose & $\begin{array}{l}\text { Fibrin } \\
\text { specific }\end{array}$ & Note \\
\hline Streptokinase & 1.5 million U over $30-60$ minute IV & No & $\begin{array}{l}\text { Highly antigenic and contraindicated in } \\
\text { previous exposure in } 6 \text { months }\end{array}$ \\
\hline $\begin{array}{l}\text { Reteplase } \\
\text { (rPA) }\end{array}$ & $\begin{array}{l}10 \text { U IV bolus initially, followed by } \\
10 \text { U IV bolus } 30 \text { minute after }\end{array}$ & Yes & \\
\hline $\begin{array}{l}\text { Alteplase } \\
\text { (tPA) }\end{array}$ & $\begin{array}{l}\text { Bolus } 15 \mathrm{mg} \mathrm{IV} \text {, followed by infusion } \\
0.75 \mathrm{mg} / \mathrm{kg} \text { for } 30 \text { minute (up } 50 \mathrm{mg}) \text { and, } \\
\text { then } 0.5 \mathrm{mg} / \mathrm{kg} \text { for } 60 \text { minutes }(\text { up to } 35 \mathrm{mg})\end{array}$ & Yes & \\
\hline $\begin{array}{l}\text { Tenecteplase } \\
\text { (TNK-tPA) }\end{array}$ & $\begin{array}{l}\text { Single IV bolus with } 30 \mathrm{mg} \text { for } 60 \mathrm{~kg} ; \\
35 \mathrm{mg} \text { for } 60-69 \mathrm{~kg} ; 40 \mathrm{mg} \text { for } 70-79 \mathrm{~kg} ;\end{array}$ & Yes & \\
\hline
\end{tabular}

Abbreviations: ACC, American College of Cardiology; AHA, American Heart Association; ESC, European Society of Cardiology.

\section{Management of STEMI with Cardiogenic Shock}

Cardiogenic shock in STEMI is highly associated with poor outcomes, with a mortality rate described between 50 to $80 \%{ }^{27-29}$ Despite introduction of both inotropic agents and mechanical circulatory support, only timely revascularization has the strongest evidence to improve morbidity and mortality outcomes. ${ }^{30}$ The benefit of early revascularization versus medical stabilization with fibrinolysis was seen in the SHOCK trial, which showed a mortality benefit by 6 months. ${ }^{31}$ In the GUSTO- 1 trial, ${ }^{32}$ patients who received tissue plasminogen activator therapy were less likely to develop cardiogenic shock. However, there remains to be a lack of placebo-controlled trials comparing the use of fibrinolytics in cardiogenic shock. Current consensus statements recommend the use of fibrino- lytics in cardiogenic shock associated with STEMI only when an early invasive approach cannot be achieved (Contemporary Management of Cardiogenic Shock).

\section{Management of STEMI with Fibrinolysis when the Diagnosis is in Doubt}

It is not uncommon for practitioners to be confronted with STEMI mimickers, potentially resulting in misdiagnosis and mismanagement. Some reports have shown that between $2.3-2.6 \%$ of patients diagnosed with STEMI do not have evidence of coronary artery stenosis. ${ }^{33,34}$ In such settings, fibrinolytic treatment would pose more harm rather than good, especially in the setting of STEMI imitators such as aortic dissection or subarachnoid hemorrhage. Exact and thorough clinical judgement should always be exercised to 
ensure correct diagnosis, not always only following STEMI protocol, when ECG is shown.

\section{Management of STEMI in PCI Capable Hospitals}

In the absence of significant treatment delays, primary $\mathrm{PCI}$ remains the preferred treatment method for patients with STEMI. According to the largest meta-analysis ${ }^{35}$ comparison between $\mathrm{PCI}$ and fibrinolysis, patients with $\mathrm{PCI}$ have high rates of thrombolysis in myocardial infarction (TIMI) 3 flow, lower rates of intracranial outcomes, shorter hospital stays, and overall lower rates of major adverse cardiovascular events.

In general, it is recommended to perform PCI in patients with STEMI within 12 hours of symptom onset. This is primarily based on previous observational studies which found lack of efficacy in reducing mortality, albeit with fibrinolysis. ${ }^{36,37}$ It is however not uncommon for STEMI patients to present later than 12 hours, variably reported from 8 to $40 \%{ }^{38-40}$ For patients with symptom onset greater than 12 hours, PCI may also be performed if there is clinical or electrocardiographic evidence of ongoing ischemia. In fact, Nepper-Christensen et al reported substantial myocardial salvage in STEMI patients with ongoing ischemic symptoms from 12 to 72 hours. $^{41}$ However for stable, asymptomatic patients with symptom onset longer than 48 to 72 hours, several studies have reported similar findings, which suggested minimal to no benefit in performing PCI compared with only medical therapy. ${ }^{42-44}$ Based on these pieces of evidence, ESC guidelines recommend against $\mathrm{PCI}$ in asymptomatic patients who have signs of an occluded culprit artery $>48$ hours after STEMI onset. Nevertheless, revascularization should still be considered in patients with ongoing symptoms or with unstable hemodynamics, as only stable patients were considered in the aforementioned studies. ${ }^{42-44}$

Antiplatelet therapy for patients undergoing primary $\mathrm{PCI}$ should include aspirin and a P2Y12 inhibitor. In the US, the preferred initial loading dose of aspirin is $325 \mathrm{mg}$, although studies have suggested lower loading doses of aspirin may be as effective. ${ }^{45}$ Following stent placement, $81 \mathrm{mg}$ daily of aspirin has been established as an adequate maintenance dose, balancing the risks of ischemic events with bleeding. ${ }^{46}$ P2Y12 antagonists inhibit the binding of adenosine disphosphate to the P2Y12 receptor and prevent platelet activation and aggregation. Of the current family of P2Y12 inhibitors, clopidogrel was initially shown to have improved outcomes in STEMI patients when added to aspirin therapy in the CLARITY-TIMI $28^{47}$ and COMMIT/CCS-2 trials, ${ }^{48}$ although in patients treated primarily with fibrinolysis. Clopidogrel's composition as a prodrug and the process of multiple enzymatic breakdowns before its activation led to the creation of faster acting P2Y12 inhibitors, prasugrel and ticagrelor. Prasugrel was studied against clopidogrel in TRITON-TIMI ${ }^{49}$ and ticagrelor against clopidogrel in PLATO, ${ }^{50}$ and both agents were shown to have decreased MACE when compared with clopidogrel. Recently, the only head-to-head comparison of prasugrel and ticagrelor was completed in the ISARREACT 5 trial. $^{51}$ Here, prasugrel and ticagrelor were compared in patients presenting with ACS, which consisted of approximately $41 \%$ STEMI. Patients who received prasugrel saw a $2.3 \%$ absolute risk reduction in the primary endpoint of MACE and, importantly, did so without a significant increase in risk of bleeding. ${ }^{51}$ Although it is unlikely a trial of this nature would be repeated, more studies comparing the efficacy of prasugrel and ticagrelor would be welcomed, as the results of ISAR-REACT 5 were unexpected. Until more data are obtained, STEMI guidelines will likely follow suit with the most current ESC recommendations for either prasugrel or ticagrelor, followed by clopidogrel if these are not available or if contraindications exist. ${ }^{11}$ The loading and maintenance doses of antiplatelet and anticoagulants used during primary PCI has been summarized in - Table 3.

Although stenting the culprit lesion causing the STEMI is the clear goal of primary PCI, the management of multivessel disease with STEMI has remained controversial. Multivessel disease is seen in approximately $50 \%$ of patient's presenting

Table 3 Recommended medications and doses for STEMI treatment (adapted from ACC/AHA and ESC guidelines) ${ }^{11,59}$

\begin{tabular}{|l|l|l|l|}
\hline Medications & Loading dose & Maintenance dose & Note \\
\hline Aspirin & $162-324 \mathrm{mg}$ & $81 \mathrm{mg}$ OD & \\
\hline Clopidogrel & $600 \mathrm{mg}$ & $75 \mathrm{mg}$ OD & \\
\hline Ticagrelor & $180 \mathrm{mg}$ & $90 \mathrm{mg} \mathrm{BID}$ & \\
\hline Prasugrel & $60 \mathrm{mg}$ & $10 \mathrm{mg}$ OD & $0.75 \mathrm{mg} / \mathrm{kg}$ BID in $>75$ YO $1 \mathrm{mg} / \mathrm{kg}$ OD in eGFR $15-30$ \\
\hline Enoxaparin & $\mathrm{n} / \mathrm{a}$ & $1 \mathrm{mg} / \mathrm{kg} \mathrm{SC} \mathrm{twice} \mathrm{a} \mathrm{day}$ & $50-70 \mathrm{IU} / \mathrm{kg}$ if concomitant abcixmab \\
\hline UFH & $70-100 \mathrm{IU} / \mathrm{kg}$ & $12-15 \mathrm{IU} / \mathrm{kg} / \mathrm{hr}$ & Not recommended as a single agent for primary PCI \\
\hline Fondaparinux & $\mathrm{n} / \mathrm{a}$ & $\mathrm{n} / \mathrm{a}$ & $1.4 \mathrm{mcg} / \mathrm{kg} / \mathrm{hr}(\mathrm{eGFR} 30-60)$ \\
\hline Bivalirudin & $0.75 \mathrm{mcg} / \mathrm{kg}$ & $1.75 \mathrm{mcg} / \mathrm{kg} / \mathrm{hr}$ & \\
\hline Abciximab & $0.25 \mathrm{mcg} / \mathrm{kg}$ & $0.125 \mathrm{mcg} / \mathrm{kg} / \mathrm{min}$ & $1 \mathrm{mcg} / \mathrm{kg} / \mathrm{min}$ if eGFR $<50$ maximum use up to $18 \mathrm{hours}$ \\
\hline Eptifibatide & $180 \mathrm{mcg} / \mathrm{kg}$ & $2 \mathrm{mcg} / \mathrm{kg} / \mathrm{min}$ & $0.075 \mathrm{mcg} / \mathrm{kg} / \mathrm{min}$ \\
\hline Tiroiban & $25 \mathrm{mcg} / \mathrm{kg}$ & $0.15 \mathrm{mcg} / \mathrm{kg} / \mathrm{min}$ & \\
\hline
\end{tabular}

Abbreviations: ACC, American College of Cardiology; AHA, American Heart Association; eGFR, estimated glomerular filtration rate; ESC, European Society of Cardiology; PCI, percutaneous coronary intervention; STEMI, ST-segment elevation myocardial infarction; UFH, unfractionated heparin. 
with STEMI. ${ }^{52}$ Previously, PCI of the nonculprit or noninfarct artery during STEMI was discouraged, as it was thought to cause harm. ${ }^{10}$ Led by advances in PCI technique and technology, a series of randomized control trials emerged, which reevaluated the management of multivessel disease in STEMI. The PRAMI, CVLPRIT, DANAMI-3 PRIMULTI, and Compare-Acute trials randomized patients presenting with STEMI to PCI of the culprit lesion only or PCI of all significant lesions. ${ }^{53-56}$ The study design of each trial varied between how the significance of nonculprit lesions were determined: angiographically or by fractional flow reserve; and when PCI of the nonculprit lesions were performed: during the index STEMI procedure, staged, or both. Nonetheless each of these trials showed significant improvement in primary outcomes of MACE in their complete revascularization arms, mostly driven by decreases in the need for repeat revascularization. Interestingly, none of the trials were able to show an isolated benefit for mortality or nonfatal MI, although trends toward mortality benefits were seen in one meta-analysis ${ }^{57}$. Recently, however, the COMPLETE trial, which separated STEMI patients into culprit lesion PCI only or staged PCI of nonculprit lesions, was able to show significant reductions in cardiovascular death and MI, which were attributed to the stronger statistical power of this study compared with its predecessors. ${ }^{58}$ Based on the above findings, the AHA modified their recommendations in the 2015 focused update ${ }^{59}$ from class III to class IIb, and the ESC provides a class IIa recommendation for multivessel disease $\mathrm{PCI}{ }^{11}$

\section{Stenting in Primary PCI}

The first interventional treatment for coronary artery disease (CAD) was percutaneous balloon angioplasty by Dr. Gruentzig in $1977 .{ }^{60}$ Despite superior benefits over thrombolysis, postprocedural patency for balloon angioplasty was not impressive, with high restenosis rates up to 30 to $50 \%$, often requiring reintervention. ${ }^{35,61-64}$ Since the introduction of stenting technology, coronary stenting has been the preferred treatment method during primary PCI. ${ }^{65-67}$ Multiple meta-analyses have shown the benefits of coronary stenting when compared with balloon angioplasty, with lower risks of reinfarction and target vessel revascularization. ${ }^{68,69}$ However, the safety and benefits of drug eluting versus bare metal stents in STEMI continues to be debated. The EXAMINATION ${ }^{70}$ and COMFORTABLE AMI ${ }^{71}$ trials both showed a decrease in target lesion reinfarction and target lesion revascularization after 1 year in patients who received 2nd generation drugeluting stents. Importantly, both trials showed a reduction in major adverse cardiovascular events after 5 years in the drugeluting stent arms without an increase in definite very late stent thrombosis. ${ }^{70,71}$ Therefore, The ACC/AHA guidelines give a Class IA recommendation for either bare metal or drug-eluting stents. ${ }^{72}$ On the contrary, ESC guidelines designate a Class IA recommendation for drug-eluting over bare metal stents, based on the lower risks of subacute and late stent thrombosis in comparison with bare metal stents. ${ }^{73,74}$

Nevertheless, the risk of drug-eluting stent thrombosis is significant, especially with early DAPT discontinuation. ${ }^{75-77}$
Thus, bare metal stents should still be considered over drugeluting stents in situations where patient compliance is in question, there is an elevated bleeding risk, or there is an anticipated surgery within the upcoming year.

\section{Management of STEMI during the COVID-19 Pandemic}

In December of 2019, a novel RNA Coronavirus was found to be causing a highly contagious viral pneumonia. This virus was named severe acute respiratory syndrome coronavirus 2 (SARS-CoV-2) and its resultant infection was named Coronavirus disease 2019 (COVID-19). As the infection spread worldwide in the spring of 2020, medical operations were severely affected, including management strategies for patients presenting with STEMI. Many centers worldwide reported a decrease in STEMI presentations combined with an increase in door to balloon times. ${ }^{78-80}$ These changes were thought to be due to patient's reluctance to present to a hospital and delays in care related to increased triage time, COVID testing, and more complex catheterization laboratory protocols. These delays in presentation and treatment led to increased rates of in-hospital mortality. ${ }^{79,80}$ Both the AHA/ACC and ESC released statements regarding the management of MI during the COVID-19 pandemic. $^{81,82}$ Fibrinolysis has been suggested as an alternative to $\mathrm{PCI}$ to reduce potential exposure to cardiac catheterization laboratory staff, but as PCI will eventually be needed in most cases, both statements list primary PCI as the preferred treatment method in patients presenting to $\mathrm{PCI}$-capable hospitals.

\section{Management of STEMI with Active or High Risk of Bleeding}

Bleeding is a well-known complication of any acute coronary syndrome (ACS), including STEMI, and can independently increase the risk of stroke, recurrent MI, or death. ${ }^{10}$ There are several components of STEMI management which can be adjusted to minimize the risk of bleeding. Fibrinolysis should be avoided if there is concern for significant bleeding ( - Table 1 for absolute and relative contraindications). If fibrinolysis is pursued, tenecteplase appears to have a safer bleeding risk profile when compared with alteplase, owed in part to tenecteplase's weight-based dosing. In a double-blind, randomized trial, patients who received tenecteplase had fewer noncerebral bleeding complications and less need for blood transfusion. ${ }^{83}$ Should PCI be performed, radial access should be considered when feasible. In the RIVAL trial, radial access did not significantly reduce the rate of major bleeding when compared with femoral access in STEMI patients, although radial access did have lower rates of vascular complications, namely, large hematomas and pseudoaneurysms requiring repair. ${ }^{84}$ In regard to anticoagulation during $\mathrm{PCI}$, the benefits of decreased major bleeding with bivalirudin when compared with heparin plus a GIIb/IIIa inhibitor were described in the HORIZONS-AMI trial ${ }^{85}$ and have been confirmed with metaanalysis. ${ }^{86}$ Finally, stent selection should be guided by the patients bleeding risk, with bare metal stents favored over drug-eluting stents in patients with high-bleeding risk. 


\section{Management of STEMI with Cardiac Arrest}

Sudden cardiac arrest is one of the most devastating clinical presentations to the hospital as the survival rate rarely exceeds $10 \% .{ }^{87}$ Importantly, the most common reason for sudden cardiac arrest is CAD, accounting for up to $80 \%$ of presentations. ${ }^{88}$ Thus, medical practitioners should be vigilant to screen for ACS, regardless of underlying conditions and demographics.

It is however still unclear whether immediate cardiac catheterization laboratory activation for unconscious patients with STEMI who survived sudden cardiac death is superior to delayed activation. Despite similar ECG morphologies, there are still many conditions mimicking true STEMI. ${ }^{33,34}$ For this reason, thoughtful decision-making should be discussed among care providers and with patients or their decision-makers, as not all patients would benefit from the invasive measures. On the other hand, sudden cardiac arrest survivors with good neurologic recovery and clear ST-segment elevations should be treated with immediate angiography and PCI if lesions are amenable, which is supported by one study, showing up to $85 \%$ of acute thrombotic coronary occlusion. ${ }^{89}$

\section{Summary and Conclusions}

The different circumstances of each STEMI patient should be taken into consideration before catheterization laboratory activation. As with most complex diseases, an individualized treatment plan is required for every patient, and as technologic and pharmacologic advancements continue, treatment strategies should continue to become more specialized.

Conflict of Interest

None declared.

\section{References}

1 Thygesen K, Alpert JS, Jaffe AS, et al; Executive Group on behalf of the Joint European Society of Cardiology (ESC)/American College of Cardiology (ACC)/American Heart Association (AHA)/World Heart Federation (WHF) Task Force for the Universal Definition of Myocardial Infarction. Fourth Universal Definition of Myocardial Infarction (2018). Circulation 2018;138(20):e618-e651

2 Benjamin EJ, Muntner P, Alonso A, et al; American Heart Association Council on Epidemiology and Prevention Statistics Committee and Stroke Statistics Subcommittee. Heart Disease and Stroke Statistics2019 Update: A Report From the American Heart Association. Circulation 2019;139(10):e56-e528

3 Torio CMMB. National inpatient hospital costs: the most expensive conditions by payer, 2013, Statistical Brief \#204. In: Healthcare Cost and Utilization Project (HCUP) Statistical Briefs. Rockville (MD): Agency for Healthcare Research and Quality (US); 2006

4 Braunwald E. The treatment of acute myocardial infarction: the past, the present, and the future. Eur Heart J Acute Cardiovasc Care 2012;1(01):9-12

5 Steg PG, Bonnefoy E, Chabaud S, et al; Comparison of Angioplasty and Prehospital Thrombolysis In acute Myocardial infarction (CAPTIM) Investigators. Impact of time to treatment on mortality after prehospital fibrinolysis or primary angioplasty: data from the CAPTIM randomized clinical trial. Circulation 2003;108(23): 2851-2856
6 Danchin N, Coste P, Ferrières J, et al; FAST-MI Investigators. Comparison of thrombolysis followed by broad use of percutaneous coronary intervention with primary percutaneous coronary intervention for ST-segment-elevation acute myocardial infarction: data from the french registry on acute ST-elevation myocardial infarction (FAST-MI). Circulation 2008;118(03):268-276

7 Sinnaeve PR, Armstrong PW, Gershlick AH, et al; STREAM investigators. ST-segment-elevation myocardial infarction patients randomized to a pharmaco-invasive strategy or primary percutaneous coronary intervention: Strategic Reperfusion Early After Myocardial Infarction (STREAM) 1-year mortality follow-up. Circulation 2014;130(14):1139-1145

8 Roule V, Ardouin P, Blanchart K, et al. Prehospital fibrinolysis versus primary percutaneous coronary intervention in ST-elevation myocardial infarction: a systematic review and meta-analysis of randomized controlled trials. Crit Care 2016;20(01):359

9 Armstrong PW, Gershlick AH, Goldstein P, et al; STREAM Investigative Team. Fibrinolysis or primary PCI in ST-segment elevation myocardial infarction. N Engl J Med 2013;368(15):1379-1387

10 O'Gara PT, Kushner FG, Ascheim DD, et al; American College of Cardiology Foundation/American Heart Association Task Force on Practice Guidelines. 2013 ACCF/AHA guideline for the management of ST-elevation myocardial infarction: a report of the American College of Cardiology Foundation/American Heart Association Task Force on Practice Guidelines. Circulation 2013;127(04):e362-e425

11 Ibanez B, James S, Agewall S, et al; ESC Scientific Document Group. 2017 ESC Guidelines for the management of acute myocardial infarction in patients presenting with ST-segment elevation: The Task Force for the management of acute myocardial infarction in patients presenting with ST-segment elevation of the European Society of Cardiology (ESC). Eur Heart J 2018;39(02):119-177

12 Hsia RY, Shen YC. Percutaneous coronary intervention in the United States: risk factors for untimely access. Health Serv Res 2016;51(02):592-609

13 Scholz KH, Maier SKG, Maier LS, et al. Impact of treatment delay on mortality in ST-segment elevation myocardial infarction (STEMI) patients presenting with and without haemodynamic instability: results from the German prospective, multicentre FITT-STEMI trial. Eur Heart J 2018;39(13):1065-1074

14 Indications for fibrinolytic therapy in suspected acute myocardial infarction: collaborative overview of early mortality and major morbidity results from all randomised trials of more than 1000 patients. Fibrinolytic Therapy Trialists' (FTT) Collaborative Group. Lancet 1994;343(8893):311-322

15 Pinto DS, Frederick PD, Chakrabarti AK, et al; National Registry of Myocardial Infarction Investigators. Benefit of transferring ST-segment-elevation myocardial infarction patients for percutaneous coronary intervention compared with administration of onsite fibrinolytic declines as delays increase. Circulation 2011;124(23):2512-2521

16 Boersma E, Maas AC, Deckers JW, Simoons ML. Early thrombolytic treatment in acute myocardial infarction: reappraisal of the golden hour. Lancet 1996;348(9030):771-775

17 De Luca G, Suryapranata H, Ottervanger JP, Antman EM. Time delay to treatment and mortality in primary angioplasty for acute myocardial infarction: every minute of delay counts. Circulation 2004;109(10):1223-1225

18 Brodie BR, Webb J, Cox DA, et al; EMERALD Investigators. Impact of time to treatment on myocardial reperfusion and infarct size with primary percutaneous coronary intervention for acute myocardial infarction (from the EMERALD Trial). Am J Cardiol 2007;99(12):1680-1686

19 Newby LK, Rutsch WR, Califf RM, et al. Time from symptom onset to treatment and outcomes after thrombolytic therapy. GUSTO-1 Investigators. J Am Coll Cardiol 1996;27(07):1646-1655

20 Berger AK, Radford MJ, Krumholz HM. Factors associated with delay in reperfusion therapy in elderly patients with acute myocardial infarction: analysis of the cooperative cardiovascular project. Am Heart J 2000;139(06):985-992 
21 McNamara RL, Herrin J, Wang Y, et al. Impact of delay in door-toneedle time on mortality in patients with ST-segment elevation myocardial infarction. Am J Cardiol 2007;100(08):1227-1232

22 de Lemos JA, Braunwald E. ST segment resolution as a tool for assessing the efficacy of reperfusion therapy. J Am Coll Cardiol 2001;38(05):1283-1294

23 Ross AM, Molhoek P, Lundergan C, et al; HART II Investigators. Randomized comparison of enoxaparin, a low-molecular-weight heparin, with unfractionated heparin adjunctive to recombinant tissue plasminogen activator thrombolysis and aspirin: second trial of Heparin and Aspirin Reperfusion Therapy (HART II). Circulation 2001;104(06):648-652

24 Sutton AG, Campbell PG, Graham R, et al. A randomized trial of rescue angioplasty versus a conservative approach for failed fibrinolysis in ST-segment elevation myocardial infarction: the Middlesbrough Early Revascularization to Limit INfarction (MERLIN) trial. J Am Coll Cardiol 2004;44(02):287-296

25 Fernandez-Avilés F, Alonso JJ, Castro-Beiras A, et al; GRACIA (Grupo de Análisis de la Cardiopatía Isquémica Aguda) Group. Routine invasive strategy within 24 hours of thrombolysis versus ischaemia-guided conservative approach for acute myocardial infarction with ST-segment elevation (GRACIA-1): a randomised controlled trial. Lancet 2004;364(9439):1045-1053

26 Cantor WJ, Fitchett D, Borgundvaag B, et al; TRANSFER-AMI Trial Investigators. Routine early angioplasty after fibrinolysis for acute myocardial infarction. N Engl J Med 2009;360(26):2705-2718

27 Killip T III, Kimball JT. Treatment of myocardial infarction in a coronary care unit. A two year experience with 250 patients. Am J Cardiol 1967;20(04):457-464

28 Goldberg RJ, Gore JM, Alpert JS, et al. Cardiogenic shock after acute myocardial infarction. Incidence and mortality from a communitywide perspective, 1975 to 1988. N Engl J Med 1991;325(16): 1117-1122

29 Hochman JS, Boland J, Sleeper LA, et al; SHOCK Registry Investigators. Current spectrum of cardiogenic shock and effect of early revascularization on mortality. Results of an International Registry. Circulation 1995;91(03):873-881

30 van Diepen S, Katz JN, Albert NM, et al; American Heart Association Council on Clinical Cardiology Council on Cardiovascular and Stroke Nursing Council on Quality of Care and Outcomes Research; and Mission: Lifeline. Contemporary Management of Cardiogenic Shock: A Scientific Statement from the American Heart Association. Circulation 2017;136(16):e232-e268

31 Hochman JS, Sleeper LA, Webb JG, et al. Early revascularization in acute myocardial infarction complicated by cardiogenic shock. SHOCK Investigators. Should We Emergently Revascularize Occluded Coronaries for Cardiogenic Shock. N Engl J Med 1999;341(09):625-634

32 Holmes DR Jr, Bates ER, Kleiman NS, et al. Contemporary reperfusion therapy for cardiogenic shock: the GUSTO-I trial experience. The GUSTO-I Investigators. Global Utilization of Streptokinase and Tissue Plasminogen Activator for Occluded Coronary Arteries. J Am Coll Cardiol 1995;26(03):668-674

$33 \mathrm{Gu}$ YL, Svilaas T, van der Horst IC, Zijlstra F. Conditions mimicking acute ST-segment elevation myocardial infarction in patients referred for primary percutaneous coronary intervention. Neth Heart J 2008;16(10):325-331

34 Widimsky P, Stellova B, Groch L, et al; PRAGUE Study Group Investigators. Prevalence of normal coronary angiography in the acute phase of suspected ST-elevation myocardial infarction: experience from the PRAGUE studies. Can J Cardiol 2006;22(13):1147-1152

35 Keeley EC, Boura JA, Grines CL. Primary angioplasty versus intravenous thrombolytic therapy for acute myocardial infarction: a quantitative review of 23 randomised trials. Lancet 2003; 361(9351):13-20

36 EMERAS (Estudio Multicéntrico Estreptoquinasa Repúblicas de América del Sur) Collaborative Group. Randomised trial of late thrombolysis in patients with suspected acute myocardial infarction. Lancet 1993;342(8874):767-772
37 Late Assessment of Thrombolytic Efficacy (LATE) study with alteplase 6-24 hours after onset of acute myocardial infarction. Lancet 1993;342(8874):759-766

38 Schömig A, Ndrepepa G, Kastrati A. Late myocardial salvage: time to recognize its reality in the reperfusion therapy of acute myocardial infarction. Eur Heart J 2006;27(16):1900-1907

39 Rogers WJ, Canto JG, Lambrew CT, et al. Temporal trends in the treatment of over 1.5 million patients with myocardial infarction in the US from 1990 through 1999: the National Registry of Myocardial Infarction 1, 2 and 3. J Am Coll Cardiol 2000;36(07):2056-2063

40 Eagle KA, Goodman SG, Avezum A, Budaj A, Sullivan CM, LópezSendón JGRACE Investigators. Practice variation and missed opportunities for reperfusion in ST-segment-elevation myocardial infarction: findings from the Global Registry of Acute Coronary Events (GRACE). Lancet 2002;359(9304):373-377

41 Nepper-Christensen L, Lønborg J, Høfsten DE, et al. Benefit from reperfusion with primary percutaneous coronary intervention beyond 12 hours of symptom duration in patients with ST-segment-elevation myocardial infarction. Circ Cardiovasc Interv 2018;11(09):e006842

42 Ioannidis JP, Katritsis DG. Percutaneous coronary intervention for late reperfusion after myocardial infarction in stable patients. Am Heart J 2007;154(06):1065-1071

43 Hochman JS, Lamas GA, Buller CE, et al; Occluded Artery Trial Investigators. Coronary intervention for persistent occlusion after myocardial infarction. N Engl J Med 2006;355(23): 2395-2407

44 Menon V, Pearte CA, Buller CE, et al. Lack of benefit from percutaneous intervention of persistently occluded infarct arteries after the acute phase of myocardial infarction is time independent: insights from Occluded Artery Trial. Eur Heart J 2009;30 (02):183-191

45 Mehta SR, Bassand JP, Chrolavicius S, et al; CURRENT-OASIS 7 Steering Committee. Design and rationale of CURRENT-OASIS 7: a randomized, $2 \times 2$ factorial trial evaluating optimal dosing strategies for clopidogrel and aspirin in patients with ST and non-STelevation acute coronary syndromes managed with an early invasive strategy. Am Heart J 2008;156(06):1080-1088.e1

46 Antithrombotic Trialists' Collaboration. Collaborative meta-analysis of randomised trials of antiplatelet therapy for prevention of death, myocardial infarction, and stroke in high risk patients. BMJ 2002;324(7329):71-86

47 Sabatine MS, Cannon CP, Gibson CM, et al; CLARITY-TIMI 28 Investigators. Addition of clopidogrel to aspirin and fibrinolytic therapy for myocardial infarction with ST-segment elevation. N Engl J Med 2005;352(12):1179-1189

48 Chen ZM, Pan HC, Chen YP, et al; COMMIT (ClOpidogrel and Metoprolol in Myocardial Infarction Trial) collaborative group. Early intravenous then oral metoprolol in 45,852 patients with acute myocardial infarction: randomised placebo-controlled trial. Lancet 2005;366(9497):1622-1632

49 Wiviott SD, Desai N, Murphy SA, et al. Efficacy and safety of intensive antiplatelet therapy with prasugrel from TRITON-TIMI 38 in a core clinical cohort defined by worldwide regulatory agencies. Am J Cardiol 2011;108(07):905-911

50 Wallentin L, Becker RC, Budaj A, et al; PLATO Investigators. Ticagrelor versus clopidogrel in patients with acute coronary syndromes. N Engl J Med 2009;361(11):1045-1057

51 Schüpke S, Neumann FJ, Menichelli M, et al; ISAR-REACT 5 Trial Investigators. Ticagrelor or prasugrel in patients with acute coronary syndromes. N Engl J Med 2019;381(16):1524-1534

52 Park DW, Clare RM, Schulte PJ, et al. Extent, location, and clinical significance of non-infarct-related coronary artery disease among patients with ST-elevation myocardial infarction. JAMA 2014;312 (19):2019-2027

53 Wald DS, Morris JK, Wald NJ, et al; PRAMI Investigators. Randomized trial of preventive angioplasty in myocardial infarction. N Engl J Med 2013;369(12):1115-1123 
54 Gershlick AH, Khan JN, Kelly DJ, et al. Randomized trial of complete versus lesion-only revascularization in patients undergoing primary percutaneous coronary intervention for STEMI and multivessel disease: the CvLPRIT trial. J Am Coll Cardiol 2015;65 (10):963-972

55 Engstrøm T, Kelbæk H, Helqvist S, et al; DANAMI-3-PRIMULTI Investigators. Complete revascularisation versus treatment of the culprit lesion only in patients with ST-segment elevation myocardial infarction and multivessel disease (DANAMI-3-PRIMULTI): an open-label, randomised controlled trial. Lancet 2015;386(9994):665-671

56 Smits PC, Abdel-Wahab M, Neumann FJ, et al; Compare-Acute Investigators. Fractional flow reserve-guided multivessel angioplasty in myocardial infarction. N Engl J Med 2017;376(13): 1234-1244

57 Elgendy IY, Mahmoud AN, Kumbhani DJ, Bhatt DL, Bavry AA. Complete or culprit-only revascularization for patients with multivessel coronary artery disease undergoing percutaneous coronary intervention: a pairwise and network meta-analysis of randomized trials. JACC Cardiovasc Interv 2017;10(04):315-324

58 Mehta SR, Wood DA, Storey RF, et al; COMPLETE Trial Steering Committee and Investigators. Complete revascularization with multivessel PCI for myocardial infarction. N Engl J Med 2019;381 (15):1411-1421

59 Levine GN, Bates ER, Blankenship JC, et al. 2015 ACC/AHA/SCAI Focused Update on Primary Percutaneous Coronary Intervention for Patients With ST-Elevation Myocardial Infarction: An Update of the 2011 ACCF/AHA/SCAI Guideline for Percutaneous Coronary Intervention and the 2013 ACCF/AHA Guideline for the Management of ST-Elevation Myocardial Infarction: A Report of the American College of Cardiology/American Heart Association Task Force on Clinical Practice Guidelines and the Society for Cardiovascular Angiography and Interventions. Circulation 2016; 133(11):1135-1147

60 Grüntzig AR, Senning A, Siegenthaler WE. Nonoperative dilatation of coronary-artery stenosis: percutaneous transluminal coronary angioplasty. N Engl J Med 1979;301(02):61-68

61 Grines CL, Browne KF, Marco J, et al; The Primary Angioplasty in Myocardial Infarction Study Group. A comparison of immediate angioplasty with thrombolytic therapy for acute myocardial infarction. N Engl J Med 1993;328(10):673-679

62 Nunn CM, O'Neill WW, Rothbaum D, et al. Long-term outcome after primary angioplasty: report from the primary angioplasty in myocardial infarction (PAMI-I) trial. J Am Coll Cardiol 1999;33 (03):640-646

63 Meier B, King SB III, Gruentzig AR, et al. Repeat coronary angioplasty. J Am Coll Cardiol 1984;4(03):463-466

64 Holmes DR Jr, Vlietstra RE, Smith HC, et al. Restenosis after percutaneous transluminal coronary angioplasty (PTCA): a report from the PTCA Registry of the National Heart, Lung, and Blood Institute. Am J Cardiol 1984;53(12):77C-81C

65 Schatz RA, Baim DS, Leon M, et al. Clinical experience with the Palmaz-Schatz coronary stent. Initial results of a multicenter study. Circulation 1991;83(01):148-161

66 Morice MC, Serruys PW, Sousa JE, et al; RAVEL Study Group. Randomized Study with the Sirolimus-Coated Bx Velocity Balloon-Expandable Stent in the Treatment of Patients with de Novo Native Coronary Artery Lesions. A randomized comparison of a sirolimus-eluting stent with a standard stent for coronary revascularization. N Engl J Med 2002;346(23):1773-1780

67 Moses JW, Leon MB, Popma JJ, et al; SIRIUS Investigators. Sirolimus-eluting stents versus standard stents in patients with stenosis in a native coronary artery. N Engl J Med 2003;349(14): 1315-1323

68 Zhu MM, Feit A, Chadow H, Alam M, Kwan T, Clark LT. Primary stent implantation compared with primary balloon angioplasty for acute myocardial infarction: a meta-analysis of randomized clinical trials. Am J Cardiol 2001;88(03):297-301
69 Nordmann AJ, Hengstler P, Harr T, Young J, Bucher HC. Clinical outcomes of primary stenting versus balloon angioplasty in patients with myocardial infarction: a meta-analysis of randomized controlled trials. Am J Med 2004;116(04):253-262

70 Sabaté M, Brugaletta S, Cequier A, et al. The EXAMINATION trial (Everolimus-Eluting Stents Versus Bare-Metal Stents in ST-Segment Elevation Myocardial Infarction): 2-year results from a multicenter randomized controlled trial. JACC Cardiovasc Interv 2014;7(01):64-71

71 Räber L, Kelbæk H, Taniwaki M, et al; COMFORTABLE AMI Trial Investigators. Biolimus-eluting stents with biodegradable polymer versus bare-metal stents in acute myocardial infarction: two-year clinical results of the COMFORTABLE AMI trial. Circ Cardiovasc Interv 2014;7(03):355-364

72 Levine GN, Bates ER, Blankenship JC, et al. 2011 ACCF/AHA/SCAI Guideline for Percutaneous Coronary Intervention: a report of the American College of Cardiology Foundation/American Heart Association Task Force on Practice Guidelines and the Society for Cardiovascular Angiography and Interventions. Circulation 2011; 124(23):e574-e651

73 Bønaa KH, Mannsverk J, Wiseth R, et al; NORSTENT Investigators. Drug-eluting or bare-metal stents for coronary artery disease. $\mathrm{N}$ Engl J Med 2016;375(13):1242-1252

74 Palmerini T, Benedetto U, Biondi-Zoccai G, et al. Long-term safety of drug-eluting and bare-metal stents: evidence from a comprehensive network meta-analysis. J Am Coll Cardiol 2015;65(23):2496-2507

75 Grines CL, Bonow RO, Casey DE Jr, et al; American Heart Association American College of Cardiology Society for Cardiovascular Angiography and Interventions American College of Surgeons American Dental Association American College of Physicians. Prevention of premature discontinuation of dual antiplatelet therapy in patients with coronary artery stents: a science advisory from the American Heart Association, American College of Cardiology, Society for Cardiovascular Angiography and Interventions, American College of Surgeons, and American Dental Association, with representation from the American College of Physicians. J Am Coll Cardiol 2007;49(06):734-739

76 Spertus JA, Kettelkamp R, Vance C, et al. Prevalence, predictors, and outcomes of premature discontinuation of thienopyridine therapy after drug-eluting stent placement: results from the PREMIER registry. Circulation 2006;113(24):2803-2809

77 Nasser M, Kapeliovich M, Markiewicz W. Late thrombosis of sirolimus-eluting stents following noncardiac surgery. Catheter Cardiovasc Interv 2005;65(04):516-519

78 Garcia S, Stanberry L, Schmidt C, et al. Impact of COVID-19 pandemic on STEMI care: an expanded analysis from the United States. Catheter Cardiovasc Interv 2020

79 De Luca G, Verdoia M, Cercek M, et al. Impact of COVID-19 pandemic on mechanical reperfusion for patients with STEMI. J Am Coll Cardiol 2020;76(20):2321-2330

80 Xiang D, Xiang X, Zhang W, et al. Management and outcomes of patients with STEMI during the COVID-19 pandemic in China. J Am Coll Cardiol 2020;76(11):1318-1324

81 Mahmud E, Dauerman HL, Welt FGP, et al. Management of acute myocardial infarction during the COVID-19 pandemic: A Consensus Statement from the Society for Cardiovascular Angiography and Interventions (SCAI), the American College of Cardiology (ACC), and the American College of Emergency Physicians (ACEP). Catheter Cardiovasc Interv 2020;96(02):336-345

82 Fulchand S. Covid-19 and cardiovascular disease. BMJ 2020;369: m1997

83 Van De Werf F, Adgey J, Ardissino D, et al; Assessment of the Safety and Efficacy of a New Thrombolytic (ASSENT-2) Investigators. Single-bolus tenecteplase compared with front-loaded alteplase in acute myocardial infarction: the ASSENT-2 double-blind randomised trial. Lancet 1999;354(9180):716-722

84 Jolly SS, Yusuf S, Cairns J, et al; RIVAL trial group. Radial versus femoral access for coronary angiography and intervention 
in patients with acute coronary syndromes (RIVAL): a randomised, parallel group, multicentre trial. Lancet 2011;377(9775): 1409-1420

85 Stone GW, Witzenbichler B, Guagliumi G, et al; HORIZONS-AMI Trial Investigators. Heparin plus a glycoprotein IIb/IIIa inhibitor versus bivalirudin monotherapy and paclitaxel-eluting stents versus bare-metal stents in acute myocardial infarction (HORIZONS-AMI): final 3-year results from a multicentre, randomised controlled trial. Lancet 2011;377(9784):2193-2204

86 Fahrni G, Wolfrum M, De Maria GL, Banning AP, Benedetto U, Kharbanda RK. Prolonged high-dose bivalirudin infusion reduces major bleeding without increasing stent thrombosis in patients undergoing primary percutaneous coronary intervention: novel insights from an updated meta-analysis. J Am Heart Assoc 2016;5 (07):e003515

87 Nichol G, Thomas E, Callaway CW, et al; Resuscitation Outcomes Consortium Investigators. Regional variation in out-of-hospital cardiac arrest incidence and outcome. JAMA 2008;300(12): 1423-1431

88 Hayashi M, Shimizu W, Albert CM. The spectrum of epidemiology underlying sudden cardiac death. Circ Res 2015;116(12):18871906

89 Garcia-Tejada J, Jurado-Román A, Rodríguez J, et al. Post-resuscitation electrocardiograms, acute coronary findings and in-hospital prognosis of survivors of out-of-hospital cardiac arrest. Resuscitation 2014;85(09):1245-1250 